\title{
Reading to the soul: Narrative imagery and moral education in early to mid-twentieth century Queensland
}

\begin{abstract}
This paper examines the way in which narratives, including stories and poetry, have been used in school texts relating to moral instruction. The paper will draw on texts used in Queensland classrooms in the early part of the twentieth century to demonstrate the ways in which description of sights and the experiences of the senses, and of exaggerated consequences, are used in narratives and poems with the intention of imparting moral lessons. The texts analysed include both those used in 'civics and morals' lessons and the Queensland School Readers, a long-running series of classroom readers designed to suit the unique needs of the state's children.
\end{abstract}

Keywords: moral instruction; civics and morals; school readers; narrative; textbooks; Australia

This paper explores the narratives - defined here as texts which tell a story, either in prose or in poetry-through which schoolchildren, through the early to mid-twentieth century, were encouraged to become moral citizens in Queensland, Australia. Analysing two texts used in Civics and Morals lessons at the beginning of the twentieth century alongside a collection of mid-century School Readers, it seeks to uncover, firstly, the types of morals taught within these texts and, secondly, the way in which such morals are supported by narrative imagery invoking the senses, particularly sights and sounds. Finally, it aims to provide a discussion of the continuities and changes in the two groups. As such, it offers an intervention into the existing historiographical literature on moral education through providing insight into an under-researched former British colony. In addition, it offers a fresh emphasis through its focus on the invocation of the senses in texts used for the purposes of moral education. 
Stories are a means through which vital cultural, historical, and moral information have always been conveyed. ${ }^{1}$ McAfee Brown states that all literature imparts some moral or other, and that one of the reasons explicitly moral literature turns readers off is that it is 'simply not good literature'. ${ }^{2}$ This suggests a distinction between literature which is didactic, explicitly moral in nature, and that which imparts a moral without that being its aim. The literature examined in this article is explicitly moral. The first two texts explored are the 1914 edition of The Children's Book of Moral Lessons, written by FJ Gould, ${ }^{3}$ and the second edition of Civics and Morals by Percival R. Cole published in $1905 .{ }^{4}$ Each of these books includes a graduated series of narratives associated with explicit morals. They are designed to be read by teachers to a class as part of a lesson. Also examined are the 1948 Queensland School Readers. These are graduated books used for the teaching of English literature in primary schools. They include images, stories, and poetry. The books for grades one through seven are examined here. Compulsory schooling at this time occurred between the ages of six and fourteen, with the grades of attainment and thus the Readers roughly mapped onto this age range. ${ }^{5}$ Each book examined includes between five and seven full colour plates alongside the black line drawings which are interspersed through the texts. The Readers are explicitly intended to encourage children to love literature and to provide useful instruction. ${ }^{6}$ Earlier editions also included a statement

\footnotetext{
${ }^{1}$ Katie Elson Anderson, “Storytelling” (SAGE, 2010), doi:10.7282/T35T3HSK.

${ }^{2}$ Robert McAfee Brown, "The Nathan Syndrome: Stories with a Moral Intention,” Religion \& Literature 16, no. 1 (1984): 50.

${ }^{3}$ Frederick James Gould, The Children's Book of Moral Lessons, 5th ed (London: Watts \& Co, 1914).

${ }^{4}$ Percival R Cole, Civics and Morals, 2nd Edition (Sydney: Angus \& Robertson, 1905).

${ }^{5}$ Queensland, "State Education Acts Amendment Act” (1912); Queensland Government, "School Admission and Progression Age: Since 1875," Queensland Government Department of Education and Training, January 10, 2013, http://education.qld.gov.au/library/edhistory/topics/age.html.

${ }^{6}$ Queensland Department of Public Instruction, Queensland School Reader: Grade V (Brisbane: Queensland Government Printer, 1948), iiv.
} 
indicating that they were designed to 'convey simple moral lessons in a form suitable for children.' ${ }^{7}$ This statement was not included in the 1948 edition; however, the moral purpose remains apparent in the narratives selected. Unlike the Civics and Morals texts, the Readers were designed for students to read, either in a class or alone. Taken together, these anthologies provide a useful sample of the diverse narratives through which Queensland children were taught to be moral citizens in the first half of the twentieth century. Citizenship was positioned in the Readers as Queensland citizenship, Australian citizenship, and British citizenship. This is despite the fact that British education policy in the colonies was an idea rather than a settled and directed course. ${ }^{8}$ Greater prominence is given in this paper to the Readers because of their longevity and lasting impact on generations of Queenslanders. They have been described by noted author David Malouf as having introduced young Queenslanders of his generation to great works of literature and having shaped their future understanding of the world. ${ }^{9}$

These anthologies should be understood in the context of an international movement toward the formal and directed provision of moral education to schoolchildren. Bruneau writes that, at the turn of the century, there were significant attempts to provide moral education to the public in various European countries. This was a project which drew the attention of influential theologians, philosophers, and other thinkers. ${ }^{10}$ Similarly, Susannah Wright points to the development of an international movement toward moral

7 Department of Public Instruction, Queensland Readers: Book I (Brisbane: Queensland Government Printer, 1933), iv.

${ }^{8}$ Clive Whitehead, "The Concept of British Education Policy in the Colonies 1850-1960," Journal of Educational Administration and History 39, no. 2 (August 2007): 161-73, doi:10.1080/00220620701342296.

9 “Old School Readers: David Malouf,” Lingua Franca (ABC Radio National, July 7, 2007), http://www.abc.net.au/radionational/programs/linguafranca/old-school-readers-davidmalouf/3236042.

10 “THE 'NEW' SOCIAL HISTORY AND THE HISTORY OF MORAL EDUCATION," Paedagogica Historica 26, no. 1 (January 1990): 14, doi:10.1080/0030923900260102. 
education in the late nineteenth and early twentieth centuries. ${ }^{11}$ This was achieved, in part, by the crusading efforts of the Moral Instruction League, one of whose main proponents, FJ Gould, wrote books of moral lessons for children in both England and India. ${ }^{12}$ Gould's The Children's Book of Moral Lessons will be discussed in this article.

Some of the results of this movement toward moral training can be found in the education for citizenship in England as described by Stephen Heathorn. He states that the values integral to late-Victorian middle- and upper-class masculine code were taught through lessons for citizenship provided to British working-class boys through the mid to late nineteenth century. Duty, discipline, and obedience to the authority of one's social betters were emphasised. ${ }^{13}$ By the turn of the twentieth century instruction in moral tone and manners, alongside instruction in natural feeling and community became necessary for the promotion of good citizenship. ${ }^{14}$ Girls were to become good citizens through association with the males in their lives rather than in themselves.

The utility of explicitly moral literature has been drawn into question. Academic literature has considered the impact of moral storytelling on children's behaviour. Results have been mixed with some narratives showing more efficacy than others. ${ }^{15}$ It is not, therefore, possible to examine moral narratives and assume that the behaviours advocated

11 “'There Is Something Universal in Our Movement Which Appeals Not Only to One Country, but to All': International Communication and Moral Education 1892-1914," History of Education 37, no. 6 (November 2008): 807-24, doi:10.1080/00467600802159064.

12 Ibid., 820.

${ }^{13}$ For Home, Country, and Race: Constructing Gender, Class, and Englishness in the Elementary School, 1880-1914, Studies in Gender and History (Toronto: University of Toronto Press, 1999), 26.

${ }^{14}$ Ibid., 31.

${ }^{15}$ See for example e.g. K. Lee et al., "Can Classic Moral Stories Promote Honesty in Children?,” Psychological Science 25, no. 8 (August 1, 2014): 1630-36, doi:10.1177/0956797614536401; Paul C Vitz, "The Use of Stories in Moral Development: New Psychological Reasons for an Old Education Method,” American Psychologist 45, no. 6 (1990): 709-20. 
therein were universally accepted and practiced, or indeed practiced at all. Despite this, moral narratives distributed to children are instructive for researchers insofar as they elucidate officially sanctioned correct ways of being and living during particular historical periods. Jackson and Gee, for example, argue that school readers contribute to understandings of the 'correct' way to do gender, finding that early school readers in New Zealand showed relatively little differentiation in terms of representations of men, women, children and families over the period $1950-2000 .{ }^{16}$ This suggests that, even as society changes, the sanctioned forms of morality taught to children through officially distributed material may fail to keep pace.

The context in which the studied anthologies were used is vital. Queensland is an Australian state and former British colony. It separated from New South Wales in 1859, making it the youngest Australian colony. From the beginning of free settlement in Australia, officials expressed concern about the impact of the environment on children of British background. In Queensland, the tropical climate led to increased concerns, particularly in relation to young people. Morality played an important role in these fears, which contributed to an expansion of the involvement of the state in socialising and developing the morals of children between 1850 and $1915 .{ }^{17}$ Moral training held an important place in Queensland education from its early history. David Ewart, the General Inspector of Schools, provided an explicit example of the way in which morality and education were entangled when, in 1897, just under forty years after Queensland separated from New South Wales, he described his understanding of a good education:

16 “'Look Janet', 'No You Look John': Constructions of Gender in Early School Reader Illustrations across 50 Years,” Gender and Education 17, no. 2 (May 2005): 126, doi:10.1080/0954025042000301410.

${ }^{17}$ Shirleene Robinson and Emily Wilson, "Preserving the Traditions of a 'Great Race': Youth and National Character in Queensland, 1859-1918,” Journal of the Royal Australian Historical Society 94, no. 2 (2008): 166-85. 
All babies are born lumps of selfishness — all of them that I have been intimate with. The last one whose acquaintance I made is just like the others. He thinks the sun and the moon, and the back-yard, and the dog's tail, and his mother's love, and his father's watch are all his, and that nothing is anybody's but his: he will begin to be educated when his love has burst his own skin, and his education will progress as the circle of his love widens, even to infinity. ${ }^{18}$

This was a powerful statement by a prominent figure in this early period of education in Queensland. As the later part of this paper demonstrates, the goal of using the 'ordinary work of the school' to moral ends was served by the use of the Queensland School Readers for instruction in English.

If a solid training in morality was viewed as an important part of education in Queensland, so too was equality of opportunity. George Randall, a colonist sponsored by the Queensland Government to give lectures in England promoting emigration, in 1882 described the colony's schools as beacons of equality, stating that 'the children of our Judges, our Members of Parliament, our Professional men, and leading Merchants, receive their education side by side with the children of the Artizan [sp] and the Labourer!' ${ }^{19}$ He explicitly contrasted Queensland state education with the multi-tiered system existent in England at the time, telling his audience that by free education 'you must not understand it as a pauperised system - because we have no paupers! ${ }^{20} \mathrm{~A}$ similar description of the equality in Queensland education was provided in a paper written for the 1886 Colonial and Indian exhibition in London. That paper stated that '[t]he tone of the Queensland primary schools is very high' and that this was achieved

${ }^{18}$ D Ewart, "Report of the General Inspector," Annual Report (Brisbane: General Inspector's Office, Department of Public Instruction, March 15, 1897).

${ }^{19}$ Australia for the Industrious or My Experience in Queensland, A Lecture by George Randall (13 Years a Colonist) (Laceby, Grimsby: H. Watson \& Son, Steam Printers, 1882), 33.

${ }^{20}$ Ibid. 
because ' $[t]$ he sons of barristers, bankers, judges, merchants, sit on the same form with the children of the farmer, mechanic, and labourer. ${ }^{21}$

Certainly this view was exaggerated for the purposes of advertisement. There were clear differences in the quality of education provided in the varying types of schools available. Further, children would attend school only with those with whom they shared a close geographic proximity, suggesting that the 'sons of barristers, bankers [and] judges' would not attend class with those of the 'farmer, mechanic, and labourer' unless they were near neighbours. Teacher training within the colony occurred through the pupilteacher system, ensuring that beginning teachers across the various schools, while they passed the same exams, were educated to different standards and by different methods. Nonetheless, the conception that the school was a place in which children, particularly boys, became equal with one another and were thus trained to take their place in society was influential. Training in morals and manners therefore took on a special significance as means of ensuring students could take their place in colonial society. This perceived equality had been bolstered in 1869 by the action of then Colonial Secretary Charles Lilley, who suddenly and without consultation abolished fees in public schools, increasing the number of school students from six to seven thousand. ${ }^{22}$ By the turn of the twentieth century state education in Queensland was free, secular, and compulsory although it would not remain secular. It was advertised as an equalising force. The following analysis explores the way in which narrative imagery was employed in this context in order to encourage children to conform to preferred ways of behaving as and becoming citizens. All of the work analysed shares an important feature in the narrative

${ }^{21}$ AJ Boyd, Colonial and Indian Exhibition. Queensland: An Introductory Essay (London: William Clowes and Sons, Limited, 1886), 13.

${ }^{22}$ HJ Gibbney, "Charles Lilley - An Uncertain Democrat," in Queensland Political Portraits 1859-1952, ed. DJ Murphy and RB Joyce (St Lucia: University of Queensland Press, 1978), 78. 
tone and the relation constructed between author/narrator and reader. Gooderham identifies four types of relationships constructed between narrators and child-readers in books for children. The first, this being the 'relationship of control', is relevant to the texts analysed here. Within the relationship of control, the narrator assumes the role of the all-knowing adult figure, providing knowledge to a young and receptive reader. ${ }^{23}$ This relationship is characterised by a distinct ideological agenda. ${ }^{24}$ While there are instances in the Readers of material written either in the voice of a child or with a focus on children, the didactic tone and focus on adult moral concerns, rather than child interests, remains. The authors of these texts do not seek to enter into the worlds of their child-readers. Instead, they aim to persuade through a combination of adult authority and narrative techniques.

\section{Civics and Morals texts}

Civics and Morals classes were introduced to Queensland as part of a sweeping and progressive reform introduced at the turn of the twentieth century. Meadmore shows that the syllabus which resulted from this reform, introduced to schools in 1905, was adapted from New South Wales - the state from which Queensland had separated in 1859. Civics and Morals as a subject was borrowed from that state's curriculum. It was taught in Queensland state schools from 1905 to 1952, when it ceased to be a subject in its own right and was absorbed into the social studies curriculum. ${ }^{25}$ Queensland's teaching in

\footnotetext{
${ }^{23}$ David W. Gooderham, "What Rough Beast. . .? Narrative Relationships and Moral Education,” Journal of Moral Education 26, no. 1 (March 1997): 64, doi:10.1080/0305724970260104. ${ }^{24}$ Ibid., 65.

${ }^{25}$ Kelsey Halbert, "History Teaching and the Values Agenda" (PhD Thesis, James Cook University, 2009), 28.
} 
Civics and Morals was, at its outset, wholly secular. ${ }^{26}$ While both Queensland and New South Wales had legislation which required education to be secular, in New South Wales the word was interpreted as meaning non-sectarian ${ }^{27}$ while in Queensland the word secular was not defined in the legislation and the regulations associated with the Education Act suggested that religious presence of any kind was unwanted in the school. School buildings, for example, could be used with the permission of the Secretary for Public Instruction, the head teacher, and the school board outside of school hours for 'any lawful purpose other than the holding of religious services.' ${ }^{28}$ This non-religious focus is reflected in the Civics and Morals texts here presented, neither of which employs explicitly Christian morals or narratives.

This secular education system was altered by a 1910 referendum which allowed for religious instruction in state schools and entrance to state schools by members of the clergy. Some of the advocates of this shift positioned Queensland's school system as responsible for providing instruction in religious and moral truths, while some opponents argued that the school was already fulfilling this role adequately. ${ }^{29}$ The Bible reading introduced to Queensland state schools as a result of this referendum would later become part of the Civics and Morals curriculum. ${ }^{30}$

\footnotetext{
${ }^{26}$ Peter Meadmore, “The Introduction of the ‘New Education’ In Queensland, Australia,” History of Education Quarterly 43, no. 3 (2003): 372-92.

${ }^{27}$ New South Wales, “An Act to Make More Adequate Provision for Public Education” (1880), sec. 7.

${ }^{28}$ Queensland, “Education Act Regulations” (1875), sec. 12.

${ }^{29}$ Clarissa Carden, "Bibles in State Schools: Moral Formation in the Late Nineteenth and Early Twentieth Century Queensland School,” History of Education Review, Forthcoming.

${ }^{30}$ See for example VE Pascoe and EF Router, "Programmes of Work for Preparatory and Grade I Comprising a Series of Studies in English, Mathematics, Geography, History, Civics and Morals, Nature Study and Needlework. In Accordance with the 1930 Syllabus Issued by The Department of Public Instruction, Q.” (Roberyson \& Provan Ltd., Educational Printers, Toowoomba, 1931), 18.
} 
The purpose of the of moral training offered in these courses is elucidated in the preface of FJ Gould's text The Children's Book of Moral Lessons, which states that:

The highest end of home and school education is to mould the child's character as a moral being: and to attain this end we must discipline the child's natural good feeling by systematic lessons in the interpretation of personal and civic conduct. ${ }^{31}$

Frederick James Gould was an English moral educationist who worked as a demonstrator for the Moral Instruction League and toured the US and India in that role. ${ }^{32}$ He was a true believer in the ability of education to change lives for the better and saw moral education as a key component of this. ${ }^{33}$ His perspective was genuinely non-religious: he was a socialist and secularist who saw Christianity as perverting humanity and morality. ${ }^{34}$ The values he espoused in his literature for children, however, were in keeping with the dominant values in Queensland at the time. Further, his work was in keeping with the then-current requirement that education be secular. His book, used in Civics and Morals classes in Queensland schools during the early 1900s, therefore serves as a useful marker of the moral traits viewed as desirable for the young during this period. The Children's Book of Moral Lessons was initially written as a series of four books (1899-1907). The version analysed here compiles aspects from all of these books into one volume. The text, written in a conversational tone, sought to impart lessons in morality through short stories or fables interwoven with explanatory narration. The subjects covered are wide-ranging and include self-control, temperance, prudence and modesty, among others. Vivid

\footnotetext{
${ }^{31}$ Gould, The Children's Book of Moral Lessons, v.

${ }^{32}$ Wright, “'There Is Something Universal in Our Movement Which Appeals Not Only to One Country, but to All,"” 817-18.

${ }^{33}$ Kevin Manton, “Filling Bellies and Brains': The Educational and Political Thought of Frederick James Gould," History of Education 30, no. 3 (May 2001): 274, doi:10.1080/00467600010029392.

${ }^{34}$ Ibid., 277.
} 
illustrations are used which encourage children to view as failures those individuals who do not live up to the standards taught therein. An example provided to illustrate the virtue of self-control is as follows:

But here is a poor man who has not this wonderful power. Look at him coming along the street. He staggers; he lurches against the people; he falls; he cannot rise without help. Alas! this is a drunkard. He has lost control of himself. He has no SELFCONTROL. ${ }^{35}$

This description is dramatic and potentially confronting. Gould's decision to speak as though the drunken man were approaching the child, to tell them to 'look', is instructive. In a text which provided no illustrations, the construction of these word-pictures was an important means of preserving the interest of children. The choice of perspective provides immediacy and highlights the disgust and sense of danger a child is expected to feel in the face of a drunkard. Invoking interest and emotions in this way was an important means of bringing the purpose of a lesson home to the children to whom it was taught.

Gould's text is a masterclass in the construction of these vivid images for moral ends. Throughout the book Gould exalts those who use their moral righteousness to help inculcate moral values in others. He makes this clear in the following passage, in which the metaphor of climbing a hill, together with images invoking sight, taste, and physical experience, are used to create a sense of excitement in the child-reader, a desire to assist others in living the virtuous life:

It is right to climb the hill. It is a happy thing to help a neighbour to climb; for then two feel joy instead of one; and two together breathe the sweet air, and look down upon the valley and the lake, and the blue river and the cottages.

Two? But, oh, if all the world could climb together up the hill of the Good Life! ${ }^{36}$

\footnotetext{
${ }^{35}$ Gould, The Children's Book of Moral Lessons, 9.

${ }^{36}$ Ibid., 53.
} 
The taste of the air, the vision of the valley - these are powerful images. They create a sense of freedom, of joy. Their aim is to make the child feel that the 'good life' is a source of joy, and that to assist others in leading such a life will bring pleasure to themselves. This passage, perhaps more than any other in the text, elucidates the role of training in morality. Children are trained to be upright, moral individuals according to the values of their time not merely to become good citizens, but also in order to participate in creating good citizens. The project of training moral, upright individuals does not, for Gould, end with the closing of his book or at the school gate: children are encouraged to spread the 'right' ways of thinking learned at school to those around them. The rewards of selfreliance, in another instance, are stated to be accrued both to the individual and to wider society.

Also used in the Queensland Civics and Morals classroom was the text Civics and Morals by Percival R Cole. Cole was a widely published scholar in the history and philosophy of education in Australia. His works, outside of Civics and Morals, include a manual for teachers, ${ }^{37}$ and an edited collection on Australian rural schools. ${ }^{38}$ He was known for the breadth of his interests and the quality of his scholarship. Educated at first in Australia, Cole studied and taught in London and New York before returning to Sydney and becoming a prominent educator in the Sydney Teachers College. ${ }^{39}$ In his view the purpose of Australian education was to promote human welfare through providing

${ }^{37}$ Percival R Cole, The Conduct of the Lesson, Records of the Education Society 30 (Sydney: Sydney Teachers College, 1917).

38 Percival R Cole, ed., The Rural School in Australia, Educational Research Series 49 (Melbourne: Melbourne University Press, 1937).

${ }^{39}$ I. S. Turner, “Cole, Percival Richard (1879-1948)," Australian Dictionary of Biography, First published 1981, http://adb.anu.edu.au/biography/cole-percival-richard-5724. 
children with: 'health, ability to earn a living and to serve the common good, social qualities, taste and sentiment, knowledge, character, and the right use of leisure. ${ }^{40}$

Cole's text was explicitly written to meet the requirements of the New South Wales syllabus for Civics and Morals. It follows a similar format to Gould's: its moral lessons are presented in the form of short narratives. Cole provides separate tales for the junior and senior syllabuses. In his introduction he states that '[a]ny good story may be used for a moral lesson', adding that '[i]f it has not a moral, give it one. ${ }^{41}$ ' He similarly exhorts teachers to '[r]emember [...] that the lives of all great men are moral studies. ${ }^{42}$ For Cole, then, the storytelling aspect of moral lessons was more important than the moral itself - if a story is told, and told well, children have the ability to draw from it an appropriate moral. Cole states that, with his book, he endeavours to present teachers with interesting subject matter without dictating the lesson plan, to provide stories and lessons which are graduated according to the various classes, to provide suggestions on topics and methods for teachers to consider, and to provide some local Australian content ${ }^{43}$ For Cole, unlike for Gould, there is little necessity to explicitly elucidate the moral intended to be imparted by a story. In fact, he states that '[i]t is neither necessary nor advisable to draw particular attention to the moral of the stories. ${ }^{44}$ He further argues that children 'understand and love parables; but they like to interpret them independently of a preceptor.' $^{45}$

Cole's text different to Gould's in other ways. Whereas Gould uses florid text with vivid descriptions, Cole’s stories are, as a rule, more succinct and pointed. Narrative

\footnotetext{
40 "Introduction," in The Rural School in Australia, ed. Percival R Cole, Educational Research Series 49 (Melbourne: Melbourne University Press, 1937), 11.

${ }^{41}$ Cole, Civics and Morals, 1.

42 Ibid., 4.

${ }^{43}$ Ibid., Preface.

${ }^{44}$ Cole, Civics and Morals, 4.

${ }^{45}$ Ibid.
} 
imagery, where it is employed, has a specific purpose - generally to heighten the tension at pivotal moments in a narrative. Cole's retelling of the fable of the Emperor and the nightingale, a story he uses to teach the virtue of kindness, features an unusually vivid scene during which the Emperor is close to death. The Emperor 'saw death sitting on his chest, putting on his golden crown, and holding his sword.' ${ }^{46}$ This is a vivid and frightening image, inviting children to use their imagination to 'see' the plight of the Emperor. This is contrasted with another sensory description, that of the beautiful sound of the nightingale's song:

\footnotetext{
"Music!” cried the Emperor, “sing to me toy nightingale.” But the toy nightingale would not sing. Just then there sounded the most lovely song. It was the little live nightingale which had come to sing to the Emperor of comfort and hope. Even death listened and said, "Go on, little nightingale, go on!”

But will you give me that splendid sword? Will you give me the Emperor’s crown?” And death gave them up for a song; and at last went out and away. ${ }^{47}$
}

Despite his injunction against didacticism, Cole makes the moral of the narrative clear, having the Emperor thank the nightingale profusely and say 'I treated you badly, and yet you have saved me from death!' ${ }^{48}$ Here the nightingale, which had previously been held captive for the Emperor's pleasure, is the personification of kindness. This was made clear in the nightingale's decision to face death for the Emperor, and to bargain for his life. The beauty of the nightingale's song is juxtaposed with the fearsome image of death sitting on the Emperor, emphasising the bird's purity and, correspondingly, the purity and beauty of those who behave kindly even after being mistreated.

\footnotetext{
${ }^{46}$ Ibid., 15.

${ }^{47}$ Ibid.

${ }^{48}$ Ibid.
} 
Death is frequently used to bring home moral lessons in Cole's text. Animals in particular are killed violently where they fail to meet the moral standards he sets out. Animals in fables represent humans - or some aspect of humans. They speak as humans do and navigate human worlds. ${ }^{49}$ The use of animal death as a narrative technique is therefore an effective way to highlight the severity of a failure to uphold moral boundaries without resorting to narratives which show human children harmed or killed. In one narrative, two asses are laden, one with flour and one with gold. The latter 'was very proud, for he had a bright, beautiful set of harnesses, with a number of pretty, jingling bells' while his partner had only a leather harness. The description of the harnesses worn by the two asses encourage children to imagine both their image and the sound they make as they walk, the ass carrying gold jingling as he steps. His pride is positioned as misguided as 'his load was the heavier of the two.' This pride is soon punished. Two robbers appear, frighten away the owners of the asses, and pierce the heart of the one who carries gold in order to steal his cargo. The story ends with his dying words:

"Ah," he said to his companion, "I wish now that I had only carried flour. But for my high honours I should now be safe and happy like yourself.” So saying, he breathed his last. ${ }^{50}$

While the beauty of the nightingale's song in the previously mentioned narrative above was intrinsic to it and used for good, the beauty of which the ass is proud is not his own. It takes the form of finery which has been decorated to mark him out as distinctive from others of his group. Further, it serves no useful purpose - the gold is the heavier load and carrying it is therefore not beneficial in any practical way. In Cole’s work, therefore,

\footnotetext{
${ }^{49}$ Howard Needler, "The Animal Fable among Other Medieval Literary Genres," New Literary History 22, no. 2 (1991): 423-39.

${ }^{50}$ Cole, Civics and Morals, 43.
} 
beautiful sights and sounds speak to goodness only where these are intrinsic to the possessor itself, rather than an accoutrement, and used for the good of others.

Elsewhere, Cole employs death as a device to highlight the perils of laziness. He states that independence cannot be attained without work, following this assertion with the tale of an ox and a calf. The ox is hard at work when a 'frisky young calf' appears and calls him a 'miserable slave.' The calf brags that he has to do no work, being free to 'get fat and amuse myself all day long.' The key sense here is again sight. Children are invited to imagine the frisky calf as opposed to the hardworking ox, which is described at this meeting as 'drawing his master’s plough up and down the field.' Sight is again employed as the moral of the story is made explicit:

But that evening the calf passed him again, this time driven by the butcher. The ox pitied the poor young calf, for he knew that he was going to be slaughtered. "Ah," he said, "it is better to work and be useful to the world after all."51

Cole's narratives are therefore constructed differently to Gould's - they use the threat of harm, rather than the beautifully described promise of good, to encourage young people to behave in prescribed ways. It is notable that, despite their differences, both authors employ the narrative voice in such a manner as to construct a relationship of control. This is perhaps in keeping with the explicit aims of and Morals texts: didacticism was an expected aspect of moral teaching.

\section{School Readers}

The various state education departments of Australia produced School Readers from the early twentieth century. These promoted a national imaginary through which Australians

\footnotetext{
51 Ibid., 30.
} 
were situated within their own state, their nation, and the British empire more broadly. School Readers were central to the experience of primary education in Australia for generations. The Queensland School Readers, initially introduced in 1915 and in use until the 1970s, were intended to represent the best pedagogical practice and to be specifically relevant to Queensland children. They had a dual purpose - to engage the children of Queensland in reading and to teach them socially acceptable values and morality. School Readers were an important part of the teaching of English in Queensland schools. Pupils would read passages aloud in class, guided by their teachers. Some sections, particularly the poems, were learned by heart. The Readers provided an introduction to Western literature which was shared by generations of Queensland school children.

The Readers were compiled with the construction of ideal future citizens in mind.$^{52}$ In this sense their purpose similar to that of the early Civics and Morals texts. There are, however, significant differences. The Queensland School Readers examined here were compiled in Queensland for the use of Queensland children. In this sense they differ from the two Civics and Morals texts examined above, which were produced in England and New South Wales respectively. They were also designed to be placed in the hands of children and, to that end, the stories therein are complemented by both black and white line drawings and full colour plates. Another difference is in the sourcing of the content: while the narratives in the two Civics and Morals texts were entirely written or adapted by their authors, the Readers contain stories, poetry, quotes, and extracts from great works of literature which have been previously published.

52 Jane McGennisken, "Huts in the Wilderness: Pioneering in School Readers," Journal of Australian Studies 34, no. 1 (March 2010): 35-47, doi:10.1080/14443050903522044. 
In some states, including Queensland, these were supplemented by regular school newspapers. Such newspapers also contributed to the development of citizenship ideals. For example, Sianan Healy's analysis of the Victorian government's monthly Reader The School Paper, as it existed after the Second World War, shows that Aboriginal people were excluded from the imagined Australian community created in these documents. Aboriginal people, while recognised, were described in a way that reinforced notions that they did not belong in modern Australian communities. ${ }^{53}$ It is, however, the Readers themselves, rather than the school newspapers, which were used for generations of children. School Readers in 1950s Victoria, another Australian state and former colony, portrayed Australian identity as centred around the home. Links to Britain were retained, however, through positioning the Queen as the Queen of Australia. ${ }^{54}$ This is in keeping with research which has shown that, up to and including the mid-twentieth century, reading lessons were lessons in morality and citizenship. ${ }^{55}$

The Readers introduced in 1915, the revised version of which are examined here, were the first tailored to Queensland school students. Prior to this, Readers sourced from elsewhere had been used, including the Irish National Readers. ${ }^{56}$ For this reason, is it little surprise that national identity is a key theme in the stories and poems published in the books. The type of national identity described is worthy of examination. McGennisken notes that the figure of the pioneering Australian was prominent in early

53 “Race, Citizenship and National Identity in The School Paper, 1946-1968," History of Education Review 44, no. 1 (June 2015): 5-22, doi:10.1108/HER-01-2015-0003.

${ }^{54}$ Vicki Macknight, "So, You Want to Feel at Home? Domesticating Australia in 1950s Primary School Education," Journal of Australian Studies 34, no. 1 (March 2010): 49-61, doi:10.1080/14443050903522051.

55 Bill Green, Phillip Cormack, and Annette Patterson, "Re-Reading the Reading Lesson: Episodes in the History of Reading Pedagogy," Oxford Review of Education 39, no. 3 (June 2013): 329-44, doi:10.1080/03054985.2013.808617.

${ }^{56}$ Queensland Department of Education and Training, “Queensland School Readers,” Education History, January 10, 2013, http://education.qld.gov.au/library/edhistory/topics/readers/. 
school readers. ${ }^{57}$ This is certainly the case in the Queensland readers, which aim to present a view of Australia as forged by brave colonial settlers. The school readers presented a heroic vision of Australian citizenship, supported by vivid imagery. The fifthgrade reader opens with a poem entitled The Australian. Its first stanza appeals to the sense of sight in the first line: 'He swings his axe in the golden morn' and sound in the second: 'The blade bites clean and free.' The stanza concludes with two lines highlighting the masculinity of the Australian and the connection to land: 'The trees must fall ere the land be ploughed/ And an axeman strong is he.' 58 This particular poem, written by Roderic Quinn, was also in use in Victorian school readers and in most of the other Australian readers. ${ }^{59}$ It therefore speaks to a national imaginary which was shared throughout the Australian states. The form of Australian citizenship expounded here is a rugged, masculine, rural citizenship. The seventh-grade reader opened with a still clearer version of this idealized rural citizenship. Its opening poem, The Nation Builders, begins: 'A handful of workers seeking the star of a strong intent-/ A handful of heroes scattered to conquer a continent.' It then describes in vivid detail the sights associated with conquering this content - 'the bones that bleach on the sandhill, and the spears that redden with blood,' and the physical pain faced by the nation builders: 'thirst and fever and famine,' 'the pitiless might of the molten skies, at noon, on the sun-cracked plain., 60

The Nation Builders, unlike The Australian, describes the experiences of a collective. It also presents a more violent image of pioneering Australia. While Indigenous Australians are not explicitly mentioned, their presence - and the violence

57 Jane McGennisken, "Huts in the Wilderness: Pioneering in School Readers," Journal of Australian Studies 34, no. 1 (March 2010): 35-47, doi:10.1080/14443050903522044.

${ }^{58}$ Queensland Department of Public Instruction, Queensland School Reader: Grade V, 1.

${ }^{59}$ McGennisken, "Huts in the Wilderness," March 2010, 38.

${ }^{60}$ Queensland Department of Public Instruction, Queensland School Reader: Grade VII (Brisbane: Queensland Government Printer, 1948), 1. 
they met at the hands of white Australians - is implied by the 'spears that redden with blood' and, potentially, 'the bones that bleach on the sandhill'. This is a heroic vision of nationhood supported by dreadful, frightening images. Here the feeling of a parched throat, a fevered brow, is invoked in order to construct a sense of heroism. Those who 'build' the nation of Australia, this poem suggests, are strong, hardy, immune to that which is unpleasant to the senses.

Visual imagery is also used to present a softer, more beautiful image of Australia. Australia Fair, a poem attributed to Maybanke Anderson and published in the grade three reader, begins:
Australia fair I love thee,
The dear land of my birth;
To me thou art the sweetest,
The brightest spot on earth. ${ }^{61}$

The poem continues, describing Australia's yellow beaches, its golden sunshine, and its mossy gullies. ${ }^{62}$ Here identification with Australia as a nation is positioned as identification with its beautiful landscape. Similarly, the grade six reader includes the poem My Country attributed to Dorathea Mackellar. The second stanza of the poem begins:

I love a sunburnt country, A land of sweeping plains...

As the poem continues, however, it paints a vivid word picture of a land that is both beautiful and frightening. It describes 'ragged mountain ranges,' 'drought and flooding

\footnotetext{
${ }^{61}$ Queensland Department of Public Instruction, Queensland School Reader: Grade III (Brisbane: Queensland Government Printer, 1948), 56.

${ }^{62}$ Ibid.
} 
rains' and indeed explicitly describes 'Her beauty and her terror.' ${ }^{63}$ In the readers, then, descriptions of the sights associated with Australia's landscape promote both joyful identification and a sense of foreboding and terror. Reading this in conjunction with The Australian and The Nation Builders creates a sense that Australian citizenship is inherently tied up with the work of conquering a land that is equally lovely and dangerous.

The same reader contains the poem Home by Veronica Mason. This poem explicitly indicates that England remains home even if the Australian child never sees it, bolstering the idea that Australian citizenship is equally British citizenship. Examples include the lines 'Grandfather lived there long ago -- / Grandfather calls it - Home' ${ }^{64}$ and 'Father has never been there yet, / But Father calls it - Home' ${ }^{65}$. The second to last stanza notes that the narrator is 'a small Tasmanian' before the last stanza completes the theme with descriptions of England.

But still, I never do forget

That Island great and old, And watch the Sun that shines on It

Blaze out a track of gold.

The descriptions continue: England 'rises clear / Across the World's Highway.' The child-narrator states 'They say its skies are grey and blue, / Its seas are green and grey.' The reader is then led to discover that the sights being described are in fact sights described to the narrator, not sights which have themselves been witnessed. Despite this, the poem concludes:

But $I$ belong to It, you see,

\footnotetext{
${ }^{63}$ Queensland Department of Public Instruction, Queensland School Reader: Grade VI (Brisbane: Queensland Government Printer, 1948), 67.

${ }^{64}$ Ibid., 77.

${ }^{65}$ Ibid., 78.
} 
And It belongs to Mine and Me,

So I shall call it - Home.' 66

Within this reader, then, two countries - Australia and England - are described as beautiful, important, essential to the child's perception of self. Children are encouraged to identify with both nations. Pride in this dual identification is therefore positioned as a moral value within these readers. Importantly, the fact that the image of England has been described to the child, rather than witnessed, is not positioned as an impediment to this identification.

Readings relating to citizenship also served to inculcate respect for elders. This occurs through examples of the hardship through which Queensland was colonised. The poem The Pioneers, written by Frank Hudson and published in the grade seven reader, describes the experience of Queensland's pioneers during their youth. It is a sanitised image, one in which hardship is limited to the work of nation building as generally conceptualised and which ignores the damaging aspects of colonialism on the original inhabitants of the country. Depicted are axes which 'rang in the woodlands' - invoking sound, the 'rough log shanty', and the 'leaking tent.' ${ }^{67}$ These are all descriptions which offer considerable fodder for the mind's eye of the young reader. Also described is the labour which allowed the people to whom the poem is addressed 'inherit the land' with cities, churches, and trains. ${ }^{68}$

This represents a patriotic appeal to history as has been found in comparable English materials. Heathorn notes that, in late nineteenth century England, history was largely taught through Readers. The insertion of this discipline into the curriculum

\footnotetext{
${ }^{66}$ Ibid., 79.

${ }^{67}$ Queensland Department of Public Instruction, Queensland School Reader: Grade V, 57-59.

${ }^{68}$ Ibid.
} 
occurred alongside an increasing public debate over the role of the schools in the production of good citizens. ${ }^{69}$ Yeandle argues that, in English schools between 1870 and 1930, the teaching of history was justified in part by its ability to teach a form of ‘enlightened patriotism', using historical knowledge to inculcate imperial and national values. $^{70}$

This focus on citizenship in relation to nation and empire represents the key difference from the Civics and Morals texts described earlier in this paper. While the Civics and Morals texts aimed to create good citizens primarily through explicit appeals to child behaviour and values, the Readers sought to construct and justify a form of patriotic citizenship tied to Queensland, to Australia, and to Britain. It worked to do so in a context in which many of the children encountering its lessons would never see England.

Despite this additional focus, it remains the case that much of the content of the Readers relates to child behaviour - to the way children ought to behave as social actors. A key theme of this content is hard work. This is positioned as valuable and desirable, with severe consequences if it is avoided. The grade one reader contains a story adapted from Collin's Graphic Story Readers in which Tommy, a boy, speaks to an old crow. The crow teases him, telling him that it is able to grow its own black suit and built its own nest. It tells him that, unlike young boys, crows never throw stones past their infancy. The crow concludes, stating that: ' $[y]$ ou are as big as twenty crows, and yet you are not as wise as one. ${ }^{71}$ Tommy, thoroughly chastised, decides to mend his lazy ways and devote

\footnotetext{
${ }^{69}$ For Home, Country, and Race, 40-41.

${ }^{70}$ Citizenship, Nation, Empire: The Politics of History Teaching in England, 1870-1930, Studies in Imperialism (Oxford: Oxford University Press, 2015).

${ }^{71}$ Queensland Department of Public Instruction, Queensland School Reader: Grade I (Brisbane: Queensland Government Printer, 1948), 11.
} 
himself to hard work. The absurdity of the image - a young boy talking to, and being chastised by, a crow - serves to render memorable the narrative’s message.

Sound is also used to emphasise the urgency of work. The poem, What the Clock Says, published in the grade two school reader provides a key example. It uses the 'tick, tick, tick' of the clock to highlight the passage of time. The sound becomes a reminder for things which must be done - examples in the poem include lessons and tasks set by one's mother. The poem concludes with the lines 'Wait not for another tick;/ What you have to do, do quick. ${ }^{72}$ Here the commands of adults - particularly the mother - are prioritised as things which must be adhered to, and must be adhered to promptly. The ticking clock is a vaguely threatening figure, denoting the slipping away of time and the ability to act. The third-grade reader continues this theme of the urgency of work with the inclusion of the parable of the ant and the cricket. This story, which features an ant who toils all summer to put away food for the winter and a cricket who plays and is left with no food, concludes with the pointed statement: '[t]hough this is a fable, the moral be good: If you live without work, you will go without food. ${ }^{\text {73 }}$ Throughout this retelling of the classic fable children are reminded of the musicality of crickets - the cricket is 'accustomed to sing', and tells the ant that he did not prepare for winter because 'My heart was so light/ That I sang day and night., ${ }^{74}$ Here the familiar sound of the cricket becomes associated with the need to work hard in order to ensure one survives.

Other prominent values in the reader are those of kindness and decency. A poem in the grade three reader entitled The Power of Kind Words provides the clearest example. It entreats children to tell their family that they love them because the words have 'an

\footnotetext{
${ }^{72}$ Queensland Department of Public Instruction, Queensland School Reader: Grade II (Brisbane: Queensland Government Printer, 1948), 5.

${ }^{73}$ Queensland Department of Public Instruction, Queensland School Reader: Grade III, 87.

${ }^{74}$ Ibid., 86-87.
} 
almost magic power / And beneath that cheering sunshine / Hearts will blossom like a flower.' ${ }^{75}$ The poem also invokes the image of life as a journey up a hill, entreating children to 'scatter' kind words 'to be as sunshine / In the dark and cloudy day.' 76

This poem, explicitly addressed to a male reader through the use of the words 'my brother', informs the child reader that their words have power - that they have the ability to, through kindness, brighten the lives of their loved ones. It is notable that, like Gould, the author of this poem invokes the metaphor of the hill to describe life. The hill implies several things - hard work to climb it, a summit, a beautiful view. The narrative imagery used within this poem indicates that the 'good life', as Gould puts it, is a journey that is almost magic in its beauty.

The same reader contains a story which also uses the promise of rewards - in this case tangible rewards of monetary value - to inculcate a desire to act with kindness and consideration to the people one encounters. In The Stone in the Road a village is inconvenienced by a large stone blocking the road. No one takes the time to move it, each villager instead stepping around it and demanding that someone else does so. After three weeks the King visits the village and announces:

\footnotetext{
"My friends, it was I who put this stone here there weeks ago. It has been seen, I suppose, by every one of you, or, at least, by every one that has passed this way. It has been left, however, just where it was; and each one has scolded his neighbour for not moving it out of the way." 77
}

The King rolls the stone over and shows the villagers that it contains a small iron box with a label which reads 'For him who lifts the stone.' The King opens the box 'and out

\footnotetext{
${ }^{75}$ Queensland Department of Public Instruction, Queensland School Reader: Grade III, 38.

${ }^{76}$ Ibid.

${ }^{77}$ Queensland Department of Public Instruction, Queensland School Reader: Grade III, 12.
} 
of it fell a beautiful ring, and a score of bright gold coins. ${ }^{78}$

This narrative suggests that a person who does the right thing - who acts to remove a circumstance disadvantaging their community, however small, will be rewarded. The use of a gold ring and coins as a reward for good behaviour is akin to the use of death in other moral narratives as a punishment for bad: it is an exaggeration, a promise which cannot be fulfilled, but which has the aim of bringing children to an understanding of that which is right more fully than would be possible through a more honest discussion of the circumstances. It is notable too that gold, the love of which led the ass to its death in one of Cole's stories, is positioned here as a reward. The beauty and instantly recognisable status of gold renders it a powerful image.

The final theme in the school readers which will be discussed here is the theme of knowledge. The school readers simultaneously position knowledge as something desirable and warn readers not to be too confident of that which they believe they know. The former position is explicitly stated: for instance, in the fifth-grade reader, the book Pilgrim's Progress is described as 'one of the best and wisest books to be found in the whole world', a book 'which all boys and girls should read. ${ }^{79}$ This, then, is a direction to young people of a means through which knowledge may be obtained. Warnings as to the consequences of a lack of knowledge are less explicit. The poem The Owl Critic by James T. Fields, for instance, details the complaints made by a youth who claims to have studied owls as to the quality of a stuffed owl in a barber shop. Children are invited to picture the owl through the litany of complaints made. The wings are 'preposterous,' the head is 'flattened', the neck 'jammed down.' ${ }^{80}$ The owl's limbs are 'unloosed,' its legs

\footnotetext{
78 Ibid.

${ }^{79}$ Queensland Department of Public Instruction, Queensland School Reader: Grade V, 140.

${ }^{80}$ Queensland Department of Public Instruction, Queensland School Reader: Grade VI, 162.
} 
'slanted,' and its neck 'screwed' into an impossible attitude. ${ }^{81}$ After his complaints have been exhausted the owl, which is alive, hops down from its perch

And then fairly hooted, as if he should say:

"Your learning's at fault this time, anyway;

Don't waste it again on a live bird, I pray.

I'm an owl: you're another. Sir Critic, good-day!" 82

The description of the owl's faults draws children in to the flawed assumption of the educated youth. Here the consequence for overconfidence is embarrassment. Other instances are more dramatic. The first-grade reader contains a story which uses animal death as a means of conveying the danger of belief in one's own knowledge and understanding over that of parents. This story features a little mouse who, flattered by a cat, and tempted with promises of cheese, chooses to ignore her mother's warnings that the cat will kill and eat her. Children are encouraged to hear the cat's words as she says 'You are such a pretty mouse. I never saw one as pretty as you before.' 83 They are also encouraged to imagine the sight of the kittens playing with a cotton reel. ${ }^{84}$ The mouse agrees to play with the cat's kittens. They begin to play and the 'Mew, mew' of the cats is described as they catch and kill the mouse. ${ }^{85}$ Finally, readers are told:

The cats played with her, and scratched her, and at last they killed and ate her. Poor Mousie! why did she not do what her mother told her? ${ }^{86}$

That the latter example - more didactic, more dramatic, without the element of humour is used in a reader intended for very young children is no accident. The techniques used

\footnotetext{
${ }^{81}$ Ibid., 163.

${ }^{82}$ Ibid.

${ }^{83}$ Queensland Department of Public Instruction, Queensland School Reader: Grade I, 17.

${ }^{84}$ Ibid., 18

${ }^{85}$ Ibid.

${ }^{86}$ Ibid.
} 
in these data to instil prescribed morality, clumsy and overly didactic though they may appear to modern eyes, are carefully tailored to their intended audience.

\section{Conclusion}

Narrative imagery depicting sights and sounds is an important part of the moral literature described above. These techniques are used to draw children into narratives and encourage them to picture in their own minds the events described. Sights and sounds have been used to instil a sense of wonder or fear in order to bring moral messages home. The Civics and Morals texts explored at the beginning of this article focused on encouraging desirable behaviours and beliefs. Values such as self-control, self-reliance, and selflessness are encouraged through prose, rather than poetry. The two authors examined here differed in their approach - Gould's work promised rewards whereas Cole's threatened punishments. Aspects of both these approaches are evident in the Queensland School Readers. These later texts, however, also promoted a sense of identification with Queensland, Australia, and Britain. This is in keeping with their origin as texts specifically designed for the use of Queensland children.

There is a surprising continuity in use of two key themes - imagery relating to hills and the death of animals - in moral narratives across both periods. In both Civics and Morals texts and the Readers, the hill is a metaphor for life. It is described in positive terms as something which must be climbed, but which can be made beautiful and enjoyable through one's care of others. Animal death is also used in a similar way across both sets of narratives. It is the ultimate form of censure, an exaggerated consequence for a failure to adhere to desired standards. The death of humans is not used in this way, however, the animals who are killed are personified, given names, personalities, and human foibles. This is an area meriting further research. 